\title{
Neo-Industrial and Sustainable Development of Russia as Mineral Resources Exploiting Country
}

\author{
Marina Prokudina ${ }^{1, *}$, Olga Zhironkina ${ }^{2}$, Oksana Kalinina $^{3}$, Magerram Gasanov $^{4}$, Felix \\ Agafonov $^{5}$
}

${ }^{1}$ Kemerovo institute (branch) of Plekhanov Russian University of Economics, Department economic security, accounting and auditing, 65099239 Kuznetsky pr., Kemerovo, Russia

${ }^{2}$ Kemerovo institute (branch) of Plekhanov Russian University of Economics, Department of Humanities, 650992, 39 Kuznetsky av., Kemerovo, Russia

${ }^{3}$ T.F Gorbachev Kuzbass State Technical University, Department of History, Philosophy and Social Sciences, 65000 Kemerovo, 28 Vesennya st, Russia

${ }^{4}$ National Research Tomsk Polytechnic University, Department of Economics, 634050, 30 Lenina st., Tomsk, Russia

${ }^{5}$ T.F Gorbachev Kuzbass State Technical University, Post-Graduate Study, 650000 Kemerovo, 28 Vesennya st, Russia

\begin{abstract}
In the Russian economy, the world leadership in the extraction of different mineral resources is combined with the potential for their processing and a significant scientific sector. Innovative development of raw materials extraction is impossible without the parallel technological modernization of the high-tech sector. In general, the complex of these processes is a neo-industrialization of the economy. Neo-industrially oriented transformation of the economy reflects complex changes in its structure, the transformation of established stable relationships between various elements of the system of social production that determine macroeconomic proportions. Neo-industrial transformations come along with the modification of economic relations associated with investments, innovations, labor and income distribution, with the process of locating productive forces and regulating the economy by the government. Neoindustrialization of economy is not only significant changes in its technological and reproductive structure (the development of high-tech industries, the integration of science and industry), but, above all, the implementation of a system structural policy of innovative development of raw material industry and the recovery of manufacturing industries on a new technological basis.
\end{abstract}

\section{Introduction}

At the level of economic reality of Russian market reforms, neo-industrial economic transformations mean a transition from an export-raw model of the reproductive system to a

\footnotetext{
*Corresponding author: prokudina63@mail.ru
} 
competitive-processing one. In it, the commodity sector plays a crucial role as a source of investments and material resources for the development of export-oriented manufacturing industries, while the high-tech and R\&D sectors form their technological basis [1-3].

The methodology of neo-industrial transformation is based on the analysis of approaches to the study of forms and directions of complex, purposeful structural changes in the economy, in the process of regulating economic relations, institutions, and the development of productive forces [4-5]. The use of this methodology in the process of developing the theoretical fundamentals of the economy neo-industrialization implies the development of a multi-level, multi-object and multi-subject impact on the national economic proportions. This influence should combine normative, indicative, program-targeted regulation and market self-regulation, alternative attractors of structural changes (for Russia - raw-specialized and neo-industrial). The application of the theoretical foundations of neo-industrialization in the practical activities of the state is determined by the vector of its structural policy, ensuring the movement towards the neo-industrial attractor in the process of forming an institutional environment, regulation of economic relations [6-9].

\section{Materials and Methods}

The methodological fundamentals of neo-industrially oriented economic transformations include an analysis of their principles and conditions.

The principles of neo-industrially oriented economic transformations are the basis on which theoretical positions, institutions, forms and instruments are formed, practical recommendations. The set of these principles includes: the priority of the state as a guarantor of neo-industrialization and regulator of the economy structure; systemic and multilevel character of its structural transformations; a combination of normative, indicative regulation and market self-regulation, the presence of a neo-industrial attractor; goal-setting and strategic programming taking into account the depth of structural problems; development of import substitution, neo-industrial state order, initial state investments, public-private platforms, target social group.

Based on these principles, the social-and-economic conditions of neo-industrialization are defined:

- institutional conditions - the establishment of institutions for interaction between business and the state that can overcome the inertia of the commodity production dominance, social and budgetary dependence on obsolete technologies and raw materials exports;

- technological conditions include the formation and development of convergent technologies - the result of interpenetration and a combination of various technological innovations, united by a common digital form of design, replication and diffusion;

- reproductive conditions consist in accelerating the renewal of the fixed capital of the manufacturing industries, in raising the rate of accumulation, in attracting investments in the branches of the 6th technological mode, in reducing the depreciation of industrial equipment, in mass investment in the digitalization of production and the launch of microprocessor equipment, new materials;

- cluster conditions - the encourage of agglomeration of new technologies as the next stage in the development of innovative clusters, based on the integration of the resource base of industrial enterprises, the innovative potential of scientific organizations and the militaryindustrial complex;

- market conditions - the promotion of innovations in mass production through publicprivate partnerships, state guarantees and state loans, subsidizing interest rates and tax incentives, regulating the interaction of innovative firms and natural monopolies;

- social conditions - target development of a stable social group necessary for the diffusion of new technologies into mass production. 
The principles and conditions of neo-industrial transformation are common to the economies of the transformational type of countries that are undergoing the process of market transformations. On their basis the theorize of neo-industrially oriented economic transformations, their mechanism, the complex of structural-transforming factors and institutional provision are being formed.

\section{Results and Discussion}

The mechanism of neo-industrially oriented economic transformations is called to unite multi-level, multi-object and multi-subject interactions of the state and business into a complex of structure-transforming neo-industrially oriented processes in the system of regulation of national reproduction. The impact of the mechanism of neo-industrially oriented reforms on the structure of economy is coordinated with the factors of its change. These factors are the forces of the macroeconomic (external market, aggregate demand, scientific and technological progress and innovation, investment, competition, macro-stabilization, supply of raw materials, labor market, institutions and ideology) and microeconomic (financial condition of enterprises, their links with commercial banks and the vertical integration of science and production) impact on national economic proportions.

Such intensive factors as scientific and technological progress, innovations and investments, market competition, financial recovery of firms greatly contribute to positive structural changes. On the contrary, extensive factors, such as international, aggregate demand, raw material availability of economy, are able both to improve the structure of economy in the process of neo-industrialization, and to strengthen the inertia of structural problems embarrassing innovation development.

Neo-industrialization of economy is impossible without strengthening the structuretransforming factors of market competition, vertical scientific and industrial integration, innovation and investment interactions among the government, banks and enterprises. Conditions for the replacement of short-term and extensive factors with long-term intensive ones (such as scientific and technological progress, vertical integration, investment of innovations, the formation of a stable social group) are defined: the diffusion of innovations from high-tech industries to processing and raw materials; state tax, credit incentives for the links of their subjects; formation of a stable social group.

The prospects for realizing these factors of neo-industrial transformation in the Russian economy are determined by their obstacles, which, in turn, reflect the specific country conditions of market transformation and the depth of structural problems.

The concept of neo-industrially oriented structural transformations unites their methodological and theoretical fundamentals, and is based on the following provisions:

- on the system-and-structural and reproductive methodology, which implies a combination of targeted government regulation and market self-regulation of macroeconomic proportions at several interconnected levels of the economic structure with maximum use of economic potential of the commodity sectors, investment resources of industrial clusters, within the maximum benefits for the manufacturing sector;

- on the concentration of the government's efforts to bring the proportions of production factors and forms of ownership, institutions, sectors and branches of economy, market models, clusters and social groups into the line with the need for innovative development of the basic sectors of the Russian economy and, on their basis, high-tech industries;

- on priority principles of neo-industrial import substitution and state procurement, parity participation of the government in the development of technological platforms and innovation clusters, targeted programming of changes in innovation, investment and social spheres; 
- on the use of resource potential of the basic sectors of the Russian economy in the development of the manufacturing sector by integrating innovative, raw material, manufacturing enterprises, banks and financial companies into high-tech holdings with the government participation;

- on the integrated application of direct framework and indirect investment, credit, tax, institutional instruments of neo-industrial transformations of economy;

- on the institutionalization of investment-and-credit, tax-financial, innovation-technology, social interactions between the state and business.

The obstacles to the neo-industrial transformations of the Russian economy are stable to the regulatory impact, and their inertia is reinforced by the institutional trap of its rental raw material model. It consists in the fact that the existing structure of the Russian economy allows achieving short-term budgetary, macro-stabilization goals, but does not contribute to neo-industrialization and economic development through a consistent change in technological structures. In such an institutional trap, the innovative development of the Russian economy is embarrassed by the stable destructive rules - the institutions of interaction of firms with the state and with each other, formed by the groups interested in the dominance of the export raw material model - the raw material and financial oligarchy and associated officials.

The rules destructive for the neo-industrialization of the Russian economy include the neglect of the public interests of innovative development, the consolidation of the fulfillment of the state's budgetary obligations over the world raw material market, the integration of Russian companies into the production chains of international corporations as a donor of raw materials and the importer of the processed products, etc. As a result neoindustrialization start of the Russian economy is constrained by the dominance of investments with a short-term effect, allowing the interest groups to profit from the situation in the commodity and financial markets, and by the lack of investment, resulting in the long term to a change of technological modes.

Overcoming the de-industrialization of the Russian economy and its move to the neoindustrial way of innovative development require the institutionalization of investment, innovation, credit, tax and financial connections between the state and business, strategic planning and targeted programming of vertical processes of raw materials, processing and high-tech manufacturing, the formation of priority social groups, the development of import substitution.

The integrator of institutional measures to ensure the neo-industrially oriented transformation of the Russian economy is their strategy. It is a program of long-term changes in the structure of the Russian economy, an integrating mechanism, and the factors of neoindustrialization, its conceptual fundamentals and institutions. The main strategic directions of neo-industrial structural policy in Russia are defined as the following:

A) The emphasis on the use of basic (natural, energy, accumulated intellectual capital and educational level of the population) and domestic (funds of the state budget and extrabudgetary funds, capitals of private investors and banks, innovative potential of clusters, special economic zones, techno-parks), rather than external resources (foreign financial capital, international marketing). To do this, it is necessary to create appropriate financial incentives for the state, promote the integration of $\mathrm{R} \& \mathrm{D}$, high-tech, manufacturing and raw materials industries.

B) The replacement of "participation in authority" (the conditions for the long-term effectiveness of Russian business that appeared in the 2000s) to "participation in innovations" through the active use of neo-dirigisme (the full use of indirect economic regulators by the state), both in financial and innovation, investment spheres, in industrial production, in the labor market. This requires the government to support small innovative entrepreneurship, 
reduce transaction costs of high technology production - at the expense of state guarantees, subsidies, and insurance.

C) Import substitution of high-tech products, which requires a reduction of the share of imports of late-industrial products - computer manufacturing, ultra-light and ultra-strong materials, microelectronics, and robotics. Neo-industrial import substitution is a necessary condition for innovative recovery of manufacturing industries and the creation of a resource base for the development of new industries. For this, a neo-industrial state order is needed a set of state contracts for carrying out import-substituting $\mathrm{R} \mathrm{\&} \mathrm{D}$, high-tech products for the needs of state corporations, state guarantees and state export crediting of at least $15 \%$ of this output. It is also important to carry out selective state support for projects of neoindustrial import substitution, taking into account the breakthrough nature of innovations, to conduct advanced imports of technologies and highly qualified specialists. To integrate these measures, a state investment program for neo-industrial import substitution is needed.

D) The development of scientific potential, import and adaptation of technologies instead of import of high-tech products and equipment. For this purpose, it is necessary to develop technological platforms and public-private partnerships in innovative clusters, transforming them into vertically integrated companies - high-tech holdings that unite research and development organizations, experimental and innovative firms, manufacturing enterprises, commercial banks, and financial companies. The core of such holdings should become commercial banks and technology platforms.

The most significant form of transforming property relations in the process of vertical integration is the creation of high-tech bank holdings with the participation of the state. Their financial centers - commercial banks - should ensure a long-term capital inflow for lending innovative projects under the state guarantees and on the security of intellectual property (high-tech mortgage).

The growth of social wellbeing of the population and the overcoming of structural desocialization of the Russian economy is the ultimate goal of neo-industrial changes. The main condition and the "conductor" of the influence of neo-industrial transformations on the social wellbeing should become the neo-industrial social group, which include:

- students - future specialists in information technologies, biochemical, radio-electronic and other high-tech industries; employees of aircraft-building industries, instrument-building enterprises; employees of military-industrial enterprises using dual-purpose technologies being diffused in the civil sector; pedagogical workers of universities participating in scientific research; private venture investors. The mechanisms for the formation of sustainable neo-industrial social group include the following:

- the state order for mass training of Russian specialists in the leading foreign universities in the areas of critical and breakthrough technologies with mandatory subsequent employment in companies residing in innovation clusters and techno-parks;

- the development of state guarantees for the employment of highly qualified employees and graduates of higher education institutions in specialties corresponding to critical technologies;

- the exemption of the payroll budget of employees in innovative firms, R \& D organizations from all taxes, and their wages - from the personal income tax;

- inclusion of the mandatory requirement for training and retraining of highly qualified personnel in investment projects supported by the Russian venture company and other state funds investing in innovations.

\section{Conclusion}

Thus, carrying out of neo-industrial transformations of the Russian economy structure is possible when taking into account a set of dominant problems of transforming economic 
relations and changing the structure of the productive forces and institutions; a combination of measures of direct, indicative impact and market self-regulation; the framework of strategic planning and targeted programming. Therefore, it is necessary to conduct a further study on the content, directions, tools and institutions of neo-industrial transformation of the Russian economy structure.

\section{References}

1. O. Krasilnikov, Structural shifts as a factor of economic growth in modern Russia (Moscow, Thesis, 2003)

2. S. Glaziev, Rus. Econ. J., 2, 3-6. (2012)

3. S. Zhironkin, M. Gasanov, O. Zhironkina, Eur. Proc. Soc. Beh. Sci. VII, 124-131 (2016)

4. D. Bell, The coming of post-industrial society. Venture in social forecasting (New York, Collman Pub., 1973)

5. R. Reich, The work of nations. Preparing ourselves for 21st Century capitalism (New York, Univ. of N.Y. Pub., 1992)

6. A.A. Baryshev, G.A. Barysheva, Eur. Proc. Soc. Beh. Sci. VII, 352-365 (2016)

7. 7. G.A. Barysheva, E.G. Novoselova, App. Mech. Mater. 682, 550-554 (2014)

8. I. Kurnysheva, S. Lykov, A. Idrisov, Economist, 10, 39-47 (2008)

9. V. Volchik, Institution and evolution economy (Rostov, UFU, 2011) 